\title{
16. CONSOLIDATION PROPERTIES OF EQUATORIAL PACIFIC OCEAN SEDIMENTS AND THEIR RELATIONSHIP TO STRESS HISTORY AND OFFSETS IN THE LEG 138 COMPOSITE DEPTH SECTIONS ${ }^{1}$
}

\author{
A.K. MacKillop, ${ }^{2}$ K. Moran, ${ }^{3}$ K. Jarrett,,${ }^{4}$ J. Farrell, ${ }^{5}$ and D. Murray ${ }^{6}$
}

\begin{abstract}
One-dimensional consolidation tests were run on 20 samples recovered from Sites 844 through 847 during Ocean Drilling Program (ODP) Leg 138. The samples consist of siliceous and calcareous oozes and siliceous clays. The consolidation behavior of these samples is strongly related to their composition. The elastic rebound and compressibility are lowest for calcareous $(>70 \%$ $\mathrm{CaCO}_{3}$ ) oozes and increase with increasing silica and clay content, with the larger values attributed primarily to high clay content. The consolidation behavior of the sediments covers the full range of stress history from overconsolidated to underconsolidated. Shipboard laboratory porosity and bulk-density measurements have been corrected to in-situ values using elastic rebound values determined from the consolidation test results. Corrected laboratory density and porosity values correlate well with downhole logging data. The elastic rebound value, the change between laboratory and corrected void ratio, and the vertical effective overburden stress were used to estimate core length expansion caused by stress relief during sampling. This expansion correlates well with recovered core lengths after rebound. The elastic response of the sediment contributes to offsets between a composite depth scale, produced by splicing together core data from holes at the same site, and the standard ODP depth scale of meters below seafloor (mbsf). A good correlation was found between the total recovered core in one hole at a site summed with the total rebounded sediment from all cores at one site and the composite section. This correlation and the good match between downhole logs and core data suggest that offsets between the composite and the ODP mbsf depths result primarily from sediment expansion, not coring gaps. However, only up to one-third of the modified core depth (med) offset can be accounted for by elastic sediment rebound. The remaining offset is likely associated with errors in the construction of the composite stratigraphic section.
\end{abstract}

\section{INTRODUCTION}

Drilling during Leg 138 was designed to recover complete, paleoclimatic records of the eastern equatorial Pacific Ocean (Fig. 1) and to provide information about the response to climate change during the last 12 m.y. Eleven sites were drilled along two north-south transects $\left(95^{\circ}\right.$ and $\left.110^{\circ} \mathrm{W}\right)$. In the eastern transect two distinct regions were drilled: the Guatemala Basin (Sites 844 and 845), which includes a significant terrigenous component, and two sites ( 846 and 847) adjacent to the Galapagos Islands. Drilling at the eastern transect was designed to examine the interaction of the equatorial current system with the Peru Current and the eastern boundary of the Pacific Ocean. The western transect comprised seven sites that crossed the equatorial Pacific current where it is fully developed and isolated from the eastern boundary currents.

In this study, we examine the consolidation behavior of sediments recovered from the four sites (844-847) comprising the eastern transect. Consolidation behavior describes the plastic and elastic deformation characteristics and stress history of the sediment. These results are used (1) to determine the amount of elastic rebound in the composite depth sections (Hagelberg et al., 1992) for each site; (2) to correct laboratory index property measurements to in-situ values for correlation with downhole measurements; and (3) to interpret the sediment stress history.

' Pisias, N.G., Mayer, L.A., Janecek, T.R., Palmer-Julson, A., and van Andel, T.H (Eds.), 1995. Proc. ODP, Sci. Results, 138: College Station, TX (Ocean Drilling Program). ${ }^{2}$ Civil Engineering, Technical University of Nova Scotia, Halifax, N.S., B3J 2X4 Canada.

${ }^{3}$ Atlantic Geoscience Centre, Bedford Institute of Oceanography, Dartmouth, N.S., B2Y 4A2, Canada.

${ }_{5}^{4}$ K \& K Geoscience, Dartmouth, N.S., B2Y 2Y4, Canada.

${ }^{5}$ Department of Oceanography, University of British Columbia, Vancouver, B.C. V6T IW5, Canada.

${ }^{6}$ Department of Geological Sciences, Brown University, Providence, RI 02912-1841,

\section{CONSOLIDATION THEORY}

Complete discussions of the theory of consolidation are presented in Taylor (1948) and Terzaghi (1943). Consolidation is the process whereby pore fluids drain from the sediment matrix when an external load is applied (e.g., sedimentation, ice loading, etc.), resulting in compression and a decrease in sediment volume. When sediment is loaded, the pore fluid pressure initially increases and then dissipates as consolidation proceeds. The rate of dissipation of excess pore pressure depends on the permeability of the sediment and the distance to a drainage path. Given enough time and a drainage path, sediment will consolidate as a function of effective pressure, equivalent to depth below seafloor. This function of porosity reduction with depth can be approximated as an exponential (Athy, 1930), empirically determined from DSDP and ODP data (e.g., Brückmann, 1989), and directly interpreted from the results of one-dimensional consolidation tests. In this study, we determine the porosity-depth function from consolidation test results.

Consolidation of a sediment can be reproduced in the laboratory. Essentially, the consolidation test measures the change in volume (void ratio) of a sample over a series of increasing stresses. The results, plotted as a consolidation curve, are used to determine the preconsolidation pressure $\left(P_{c}^{\prime}\right)$ using the Casagrande construction method (Casagrande, 1936). The beginning of the curve ( $a$ to $b$; Fig. 2 ) represents reloading of the sample. Little change in the void ratio is observed, because the sediment has already experienced this stress. The straight line portion of the curve ( $c$ to $d$; Fig. 2) is called the virgin compression curve. It results from the application of stresses greater than those previously experienced by the sediment. The slope of the virgin compression curve $\left(C_{c}\right)$ represents the reduction of void ratio as a function of effective pressure. Consequently, $C_{c}$ defines the porosity-depth function for the sediment tested. The curved part ( $b$ to $c$; Fig. 2) is the transition between reloading and new loads. The maximum curvature of the transition curve defines the position of the preconsolidation pressure, sometimes referred to as the maximum past stress $\left(P_{c}^{\prime}\right)$. The unloaded portion of the curve ( $d$ to $e ;$ Fig. 2) represents the elastic rebound of the material. The slope of this por- 


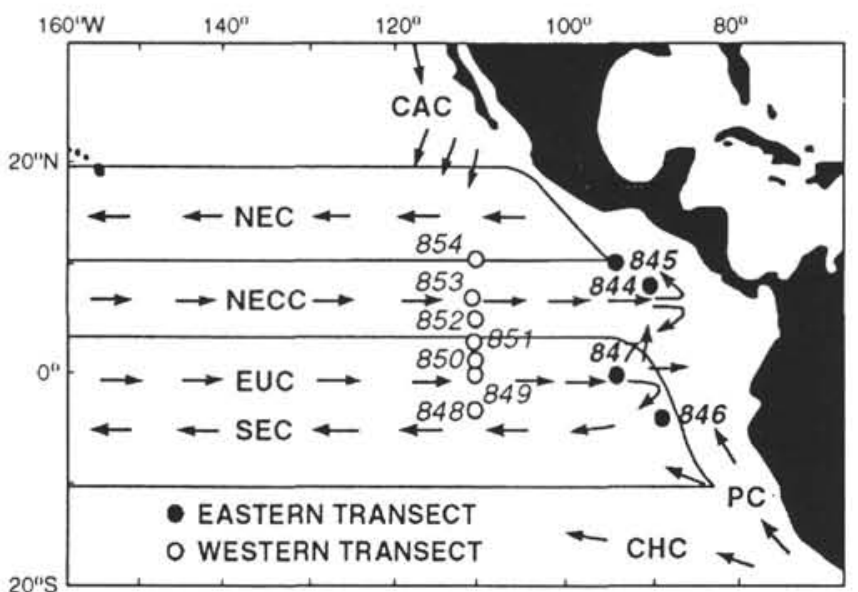

Figure 1. Location of study area showing the oceanographic circulation system of the eastern equatorial Pacific Ocean. $\mathrm{CAC}=$ California Current; $\mathrm{NEC}=$ North Equatorial Current, NECC $=$ North Equatorial Countercurrent, EUC $=$ Equatorial Undercurrent, $\mathrm{SEC}=$ South Equatorial Current, $\mathrm{PC}=$ Peru Current, and $\mathrm{CHC}=$ Chile Current. In this study, samples were tested from sites on the eastern transect (modified from Mayer, Pisias, Janecek, et al., 1992).

tion of the curve is defined as the coefficient of expansion $\left(C_{r}\right)$, which characterizes the sediment elastic response to stress relief (i.e., during the sampling process).

The overconsolidation ratio (OCR) is used to infer the state of the sample stress history. The OCR is defined as the ratio of preconsolidation stress $\left(P_{c}^{\prime}\right)$ to existing effective vertical overburden stress $\left(P_{o}^{\prime}\right)$. If the $\mathrm{OCR}=1$, the sample is normally consolidated. An OCR $>1$ indicates an overconsolidated sample, and an OCR $<1$ indicates an underconsolidated sample. A normally consolidated sediment is one that has never been subjected to an effective stress greater than the existing overburden stress. An overconsolidated sediment has been subjected to an effective stress greater than the existing overburden. For example, a sediment is overconsolidated when overburden is removed due to erosion or mass wasting. In this case, sediment is initially normally consolidated to a preconsolidation stress that is equal to its overburden stress. After removal of sediment, the underlying sediment will maintain the same preconsolidation stress, but the overburden stress will be decreased. Thus, $P_{c}^{\prime}$ will be greater than $P_{o}^{\prime}$ and an OCR $>1$ results. An underconsolidated sediment is not fully consolidated under the existing overburden pressure and thus maintains a high porosity relative to its position in depth below seafloor.

\section{METHODS}

Index properties were measured on board the JOIDES Resolution, and the methods used have been described in the Leg 138 Initial Reports volume (Mayer, Pisias, Janecek, et al., 1992). Consolidation tests were performed on 20 samples for this study. Whole-round samples, $10 \mathrm{~cm}$ long, were cut from the core sections. To prevent desiccation, the samples were capped, sealed in wax, and stored in refrigerated seawater until testing.

Samples were cut and trimmed just prior to conducting the test to prevent moisture loss. The whole-round sample was extruded into a thin-walled ring ( $6.2 \mathrm{~cm}$ diameter, $4 \mathrm{~cm}$ high) with a bevelled cutting edge. The sample was trimmed with fine wire to a height between 2 and $2.5 \mathrm{~cm}$, transferred to the consolidation ring, and placed between two porous stones. The inside wall of the consolidation ring is polished stainless steel, which reduces friction between the wall and the sample. Sample trimmings were weighed and dried to determine water content, which was used with the known volume and mass of

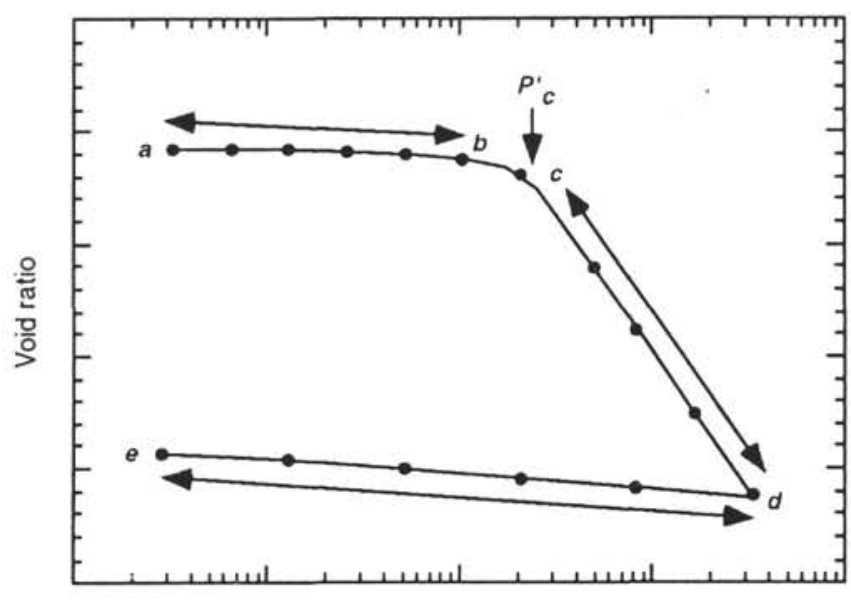

Effective stress ( $\mathrm{kPa}$ )

Figure 2. Example of a typical void ratio $(e)$ vs. effective stress $\left(\log P^{\prime}\right)$ plot. The curve can be described in four parts: $a$ to $b$ represents reloading of the sample; $b$ to $c$ is a transition zone where the maximum point of curvature represents the position of the preconsolidation stress $\left(P_{c}^{\prime}\right) ; c$ to $d$ is the virgin compression curve; and $d$ to $e$ is the unloading or rebound portion of the curve.

the actual sample to calculate the initial void ratio $\left(e_{o}\right)$. The measured water content and calculated void ratio and porosity give similar results to those obtained at sea, indicating that no desiccation of the samples occurred during transport and storage.

The tests were performed in two back-pressured consolidometers. Removal of sediment from the marine environment permits the formation of air bubbles, which may become trapped in the pore fluid and have considerable effect on the consolidation and permeability of the sediments. The application of back pressure redissolves any air bubbles. Back-pressured consolidometers have been described by Lowe et al. (1964). The samples were allowed to adjust to the back pressure for a minimum of $12 \mathrm{hr}$ before incremental loading was started. A standard load increment ratio of 1 was used (Silvestri et al., 1986), and the samples were double-drained (top and bottom).

\section{RESULTS \\ Consolidation Behavior}

It has been reported by Demars (1982), Pittenger (1989), Nobes (1991), Marsters and Christian (1990), and Marsters and Manghnani (1993) that the biogenic components of marine sediments influence their physical properties and consolidation behavior. Sediment classification was determined for this study using compositional analysis (Table 1). Carbonate and opal contents were measured following the technique of Murray et al. (this volume). Clay content was estimated as the difference; $100 \%-(\%$ carbonate $+\%$ opal $)$. Clay percentages determined on board the ship from smear slides were consistently underestimated, when compared to shore-based analyses. The samples have been classified into calcareous ooze, siliceous calcareous ooze, and siliceous clay. The calcareous ooze consisted of greater than $65 \%$ carbonate; the siliceous calcareous ooze consisted of $30 \%$ to $60 \%$ carbonate and greater than $25 \%$ opal; and the siliceous clay consisted of greater then $70 \%$ clay (Table 1 ).

\section{Calcareous Ooze}

The calcareous sediments tested in this study consisted predominantly of foraminifer nannofossil ooze, foraminifer diatom nannofossil ooze, and foraminifer diatom clayey nannofossil ooze. The calcareous ooze consisted of greater than $65 \%$ carbonate, less than $25 \%$ opal, and 
Table 1. Compositional summary of consolidation test samples.

\begin{tabular}{|c|c|c|c|c|c|c|c|c|c|c|}
\hline Site & (Test) & $\begin{array}{c}\text { Sediment } \\
\text { type }\end{array}$ & $\begin{array}{l}\text { Depth } \\
\text { (mbsf) }\end{array}$ & $\begin{array}{c}\text { Nannofossils } \\
(\%)\end{array}$ & $\begin{array}{c}\text { Diatoms } \\
(\%)\end{array}$ & $\begin{array}{c}\text { Foraminifers } \\
(\%)\end{array}$ & $\begin{array}{c}\text { Radiolarians } \\
(\%)\end{array}$ & $\begin{array}{c}\text { Carbonate } \\
(\%)\end{array}$ & $\begin{array}{l}\text { Opal } \\
(\%)\end{array}$ & $\begin{array}{l}\text { Clay } \\
(\%)\end{array}$ \\
\hline $844 \mathrm{~A}$ & (13) & SC & 5.85 & 5 & 60 & - & 15 & 5.6 & 20.5 & 73.9 \\
\hline $844 \mathrm{~B}$ & (11) & $\mathrm{CO}$ & 78.40 & 80 & 15 & 5 & - & 84.3 & 5.7 & 10.0 \\
\hline $844 \mathrm{~B}$ & (12) & $\mathrm{CO}$ & 165.40 & 75 & 10 & 10 & 5 & 79.3 & 9.4 & 10.8 \\
\hline $845 \mathrm{C}$ & (16) & SC & 25.90 & - & 25 & - & 30 & 6.3 & 23.4 & 70.3 \\
\hline $845 B$ & (14) & SC & 46.40 & - & 20 & - & 20 & 3.6 & 20.7 & 75.7 \\
\hline $845 \mathrm{~A}$ & (15) & SC & 88.00 & 5 & 15 & - & 20 & 4.2 & 8.2 & 87.6 \\
\hline $845 \mathrm{~A}$ & (19) & SC & 129.00 & - & 5 & - & 45 & 1.5 & 13.4 & 85.1 \\
\hline $845 \mathrm{~A}$ & (18) & $\mathrm{CO}$ & 167.00 & 75 & - & 10 & 15 & 80.3 & 2.1 & 17.6 \\
\hline $846 \mathrm{~A}$ & (20) & $\mathrm{SCO}$ & 3.05 & 30 & 40 & 25 & 5 & 51.1 & 25.6 & 23.3 \\
\hline $846 \mathrm{~A}$ & (1) & SCO & 6.97 & 50 & 25 & 20 & 5 & 52.6 & 28.9 & 18.5 \\
\hline 846D & (3) & $\mathrm{CO}$ & 18.48 & 60 & 15 & 20 & 5 & 72.5 & 15.3 & 11.9 \\
\hline $846 \mathrm{D}$ & (5) & $\mathrm{SCO}$ & 36.90 & 55 & 15 & 15 & 5 & 55.9 & 30.2 & 13.9 \\
\hline $846 \mathrm{D}$ & (9) & SCO & 113.70 & 55 & 25 & 15 & 5 & 47.7 & 27.9 & 24.4 \\
\hline $846 \mathrm{D}$ & (7) & $\mathrm{CO}$ & 163.90 & 65 & 20 & 5 & 5 & 66.8 & 23.1 & 10.1 \\
\hline $847 \mathrm{~A}$ & (2) & SCO & 4.40 & 70 & 15 & 10 & - & 29.7 & 31.6 & 38.7 \\
\hline 847D & (4) & $\mathrm{CO}$ & 12.50 & 75 & 5 & 10 & 5 & 81.2 & 8.2 & 10.6 \\
\hline 847D & (6) & $\mathrm{SCO}$ & 31.50 & 55 & 20 & 15 & 5 & 48.7 & 31.4 & 19.9 \\
\hline $847 \mathrm{~B}$ & (10) & $\mathrm{SCO}$ & 91.40 & 60 & 25 & 5 & 10 & 55.8 & 26.0 & 18.2 \\
\hline $847 \mathrm{~B}$ & (8) & SCO & 134.40 & 60 & 25 & 5 & 5 & 49.5 & 42.7 & 7.8 \\
\hline
\end{tabular}

Note: $\mathrm{SC}=$ siliceous clay, $\mathrm{CO}=$ calcareous ooze, $\mathrm{SCO}=$ siliceous calcareous ooze .

Table 2. Summary of consolidation test results.

\begin{tabular}{|c|c|c|c|c|c|c|c|c|c|c|c|}
\hline Site & (Test) & $\begin{array}{l}\text { Sediment } \\
\text { type }\end{array}$ & $\begin{array}{l}\text { Depth } \\
\text { (mbsf) }\end{array}$ & $\begin{array}{l}\text { Void } \\
\text { ratio }\end{array}$ & $\begin{array}{c}P_{o}^{\prime} \\
(\mathrm{kPa})\end{array}$ & $\begin{array}{c}P_{C}^{\prime} \\
(\mathrm{kPa})\end{array}$ & OCR & $\begin{array}{c}C_{\mathrm{y}} \\
\left(\mathrm{cm}^{2} / \mathrm{s}\right)\end{array}$ & $C_{c}$ & $C_{r}$ & $\begin{array}{r}\mathrm{K} \times 10^{-7} \\
(\mathrm{~cm} / \mathrm{s})\end{array}$ \\
\hline $844 \mathrm{~A}$ & (13) & SC & 5.85 & 8.15 & 12.1 & 70 & 5.79 & 0.0058 & 3.40 & 0.175 & 14.0 \\
\hline $844 \mathrm{~B}$ & (11) & $\mathrm{CO}$ & 78.40 & 2.10 & 197.8 & 400 & 2.02 & 0.0253 & 0.40 & 0.040 & 3.9 \\
\hline $844 \mathrm{~B}$ & (12) & $\mathrm{CO}$ & 165.40 & 2.10 & 644.4 & 900 & 1.40 & 0.0141 & 0.35 & 0.059 & 1.2 \\
\hline $845 \mathrm{C}$ & (16) & SC & 25.90 & 9.67 & 32.7 & 75 & 2.29 & 0.0184 & 5.02 & 0.161 & 36.0 \\
\hline $845 \mathrm{~B}$ & (14) & SC & 46.40 & 8.71 & 61.3 & 105 & 1.71 & 0.0052 & 4.17 & 0.204 & 15.0 \\
\hline $845 \mathrm{~A}$ & (15) & SC & 88.00 & 10.75 & 124.5 & 157 & 1.26 & 0.0066 & 5.20 & 0.374 & 6.3 \\
\hline $845 \mathrm{~A}$ & (19) & SC & 129.00 & 10.50 & 177.9 & 235 & 1.32 & 0.0039 & 7.95 & 0.309 & 5.3 \\
\hline $845 \mathrm{~A}$ & (18) & $\mathrm{CO}$ & 167.00 & 2.92 & 275.0 & 384 & 1.40 & 0.0108 & 1.21 & 0.062 & 2.8 \\
\hline $846 \mathrm{~A}$ & (20) & SCO & 3.05 & 5.55 & 6.5 & 80 & 12.31 & 0.0145 & 2.19 & 0.074 & 13.0 \\
\hline $846 \mathrm{~A}$ & (1) & SCO & 6.97 & 3.83 & 15.0 & 120 & 8.00 & 0.0121 & 1.19 & 0.115 & 8.7 \\
\hline $846 \mathrm{D}$ & (3) & $\mathrm{CO}$ & 18.48 & 2.71 & 50.8 & 320 & 6.30 & 0.0183 & 1.56 & 0.070 & 4.9 \\
\hline $846 \mathrm{D}$ & (5) & SCO & 36.90 & 5.15 & 109.3 & 320 & 2.93 & 0.0156 & 1.61 & 0.115 & 6.0 \\
\hline $846 \mathrm{D}$ & (9) & SCO & 113.70 & 3.85 & 305.0 & 370 & 1.21 & 0.0178 & 1.26 & 0.087 & 7.7 \\
\hline $846 \mathrm{D}$ & (7) & $\mathrm{CO}$ & 163.90 & 2.55 & 504.0 & 520 & 1.03 & 0.0204 & 0.81 & 0.071 & 2.9 \\
\hline $847 \mathrm{~A}$ & (2) & SCO & 4.40 & 6.65 & 13.3 & 57 & 4.29 & 0.0110 & 2.63 & 0.167 & 12.2 \\
\hline 847D & (4) & $\mathrm{CO}$ & 12.50 & 2.79 & 37.6 & 102 & 2.71 & 0.0156 & 0.68 & 0.061 & 15.5 \\
\hline 847D & (6) & SCO & 31.50 & 3.83 & 92.9 & 130 & 1.40 & 0.0117 & 1.66 & 0.072 & 12.3 \\
\hline $847 \mathrm{~B}$ & (10) & SCO & 91.40 & 5.70 & 243.2 & 205 & 0.84 & 0.0070 & 2.35 & 0.158 & 6.9 \\
\hline $847 \mathrm{~B}$ & (8) & SCO & 134.40 & 4.74 & 392.7 & 260 & 0.66 & 0.0114 & 1.85 & 0.160 & 6.2 \\
\hline
\end{tabular}

Note: $\mathrm{SC}=$ siliceous clay, $\mathrm{CO}=$ calcareous ooze, $\mathrm{SCO}=$ siliceous calcareous ooze .

less than $20 \%$ clay. Consolidation tests were conducted on six samples from Sites 844 through 848 . The calcareous sediments are characterized by relatively low initial void ratios $(2.10-2.92)$ and low compression and expansion coefficients. $C_{c}$ values range from 0.35 to 1.56 , with a mean of 0.71 (Table 2) and are typical of calcareous sediment reported by others. Marsters and Manghnani (1993) measured $C_{c}$ values ranging from 0.4 to 0.7 for foraminifer oozes $\left(\mathrm{CaCO}_{3}>80 \%\right)$ from the Ontong Java Plateau in the western Pacific Ocean. Demars (1982) obtained $C_{c}$ values from 0.35 to 0.65 , for calcareous sediments $\left(\mathrm{CaCO}_{3}\right)$ from the eastern Atlantic Ocean, off the coast of North Africa. Valent et al. (1982) measured a $C_{c}$ value of 0.75 for a deep-sea calcareous ooze from the central Venezuelan Basin. Expansion indexes $\left(C_{r}\right)$, which represent elastic rebound, range from 0.040 to 0.072 with an average of 0.063 . This range of $C_{r}$ values is characteristic of calcareous marine sediments. Marsters and Manghnani (1993) reported $C_{r}$ values ranging from 0.01 to 0.04 ; and Demars (1982) measured rebounds ranging from 0.04 to 0.11 .

Each $e-\log P^{\prime}$ curve was interpreted for its preconsolidation stress. $P_{c}^{\prime}$ values were identified for calcareous sediment using the $e-\log P^{\prime}$ plot (Fig. 3A). Preconsolidation stresses ranged from $102 \mathrm{kPa}$ in the shallowest calcareous sample to $900 \mathrm{kPa}$ in the deepest sample (Table 2). All calcareous ooze samples are in the overconsolidated range.

\section{Siliceous Calcareous Ooze}

The siliceous calcareous sediments consisted of varying amounts of clay, diatoms, radiolarians, nannofossils and foraminifers. Carbonate content ranged from $30 \%$ to $60 \%$, opal content was greater than $25 \%$, and clay content was less than $40 \%$ (Table 1). Consolidation tests were performed on nine samples (Table 2) from Sites 846 and 

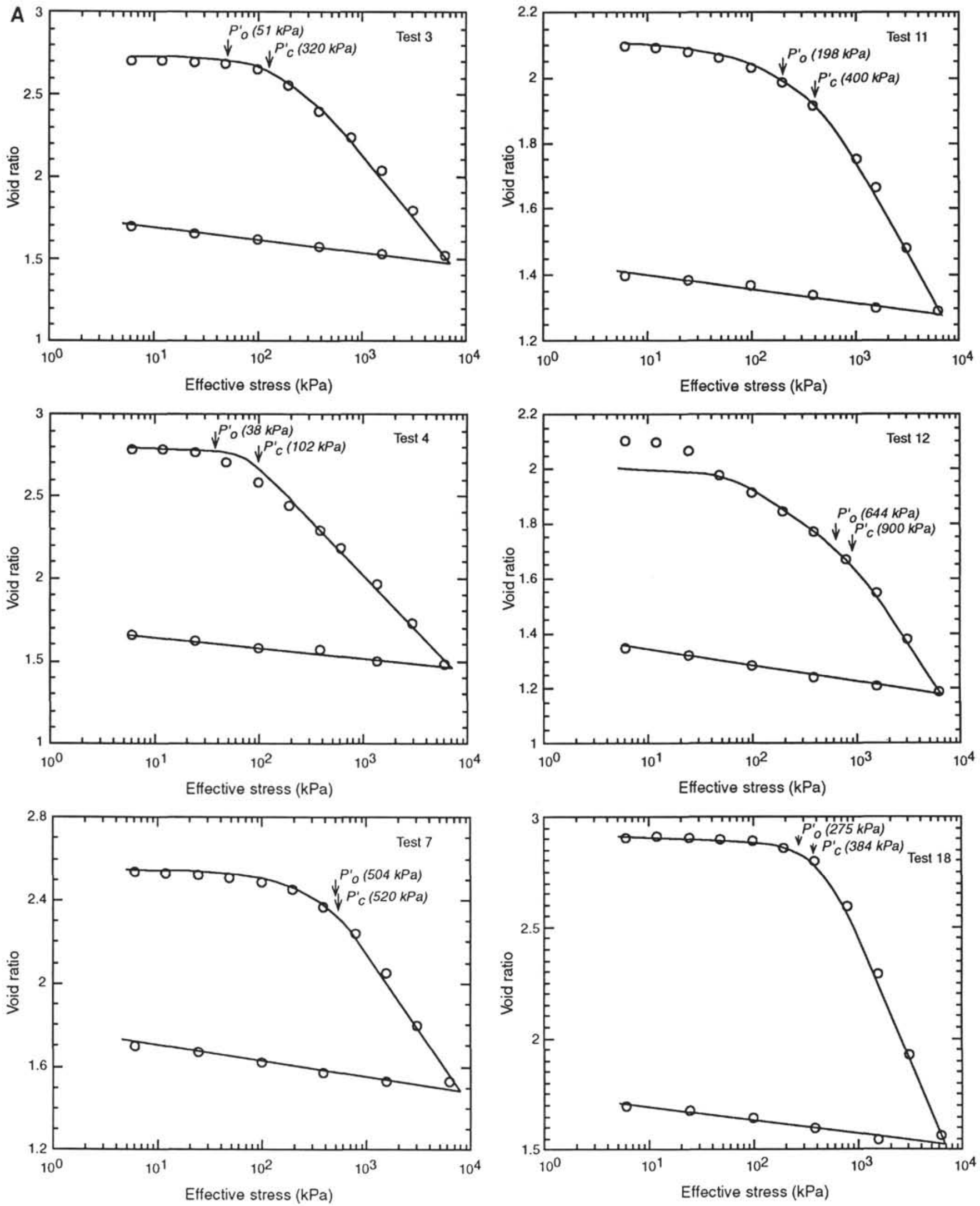

Figure 3. Consolidation test results of void ratio $(e)$ vs. effective stress $\left(\log P^{\prime}\right)$. A. Calcareous ooze. B. Siliceous calcareous ooze. C. Siliceous ooze. 

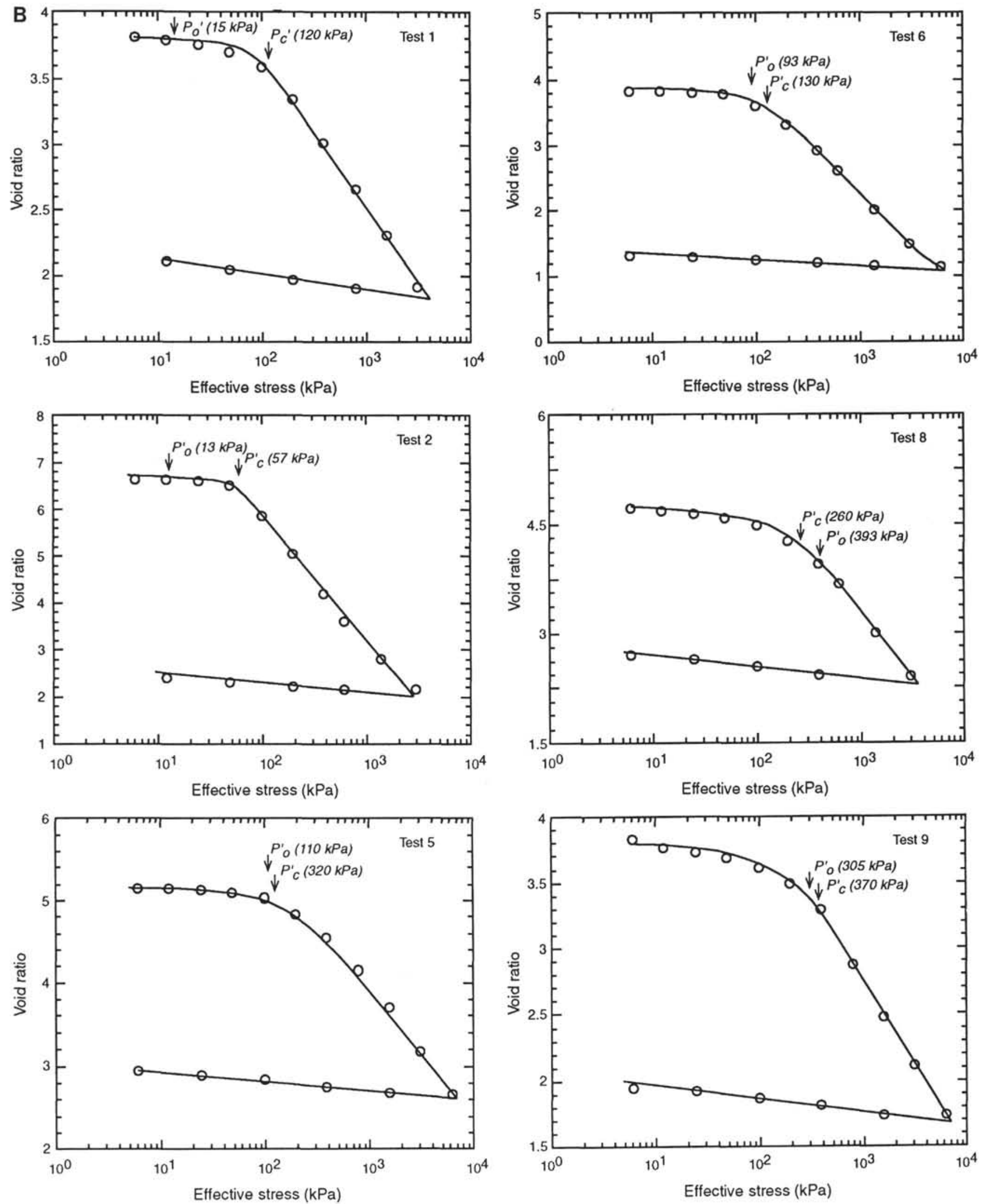

Figure 3 (continued). 

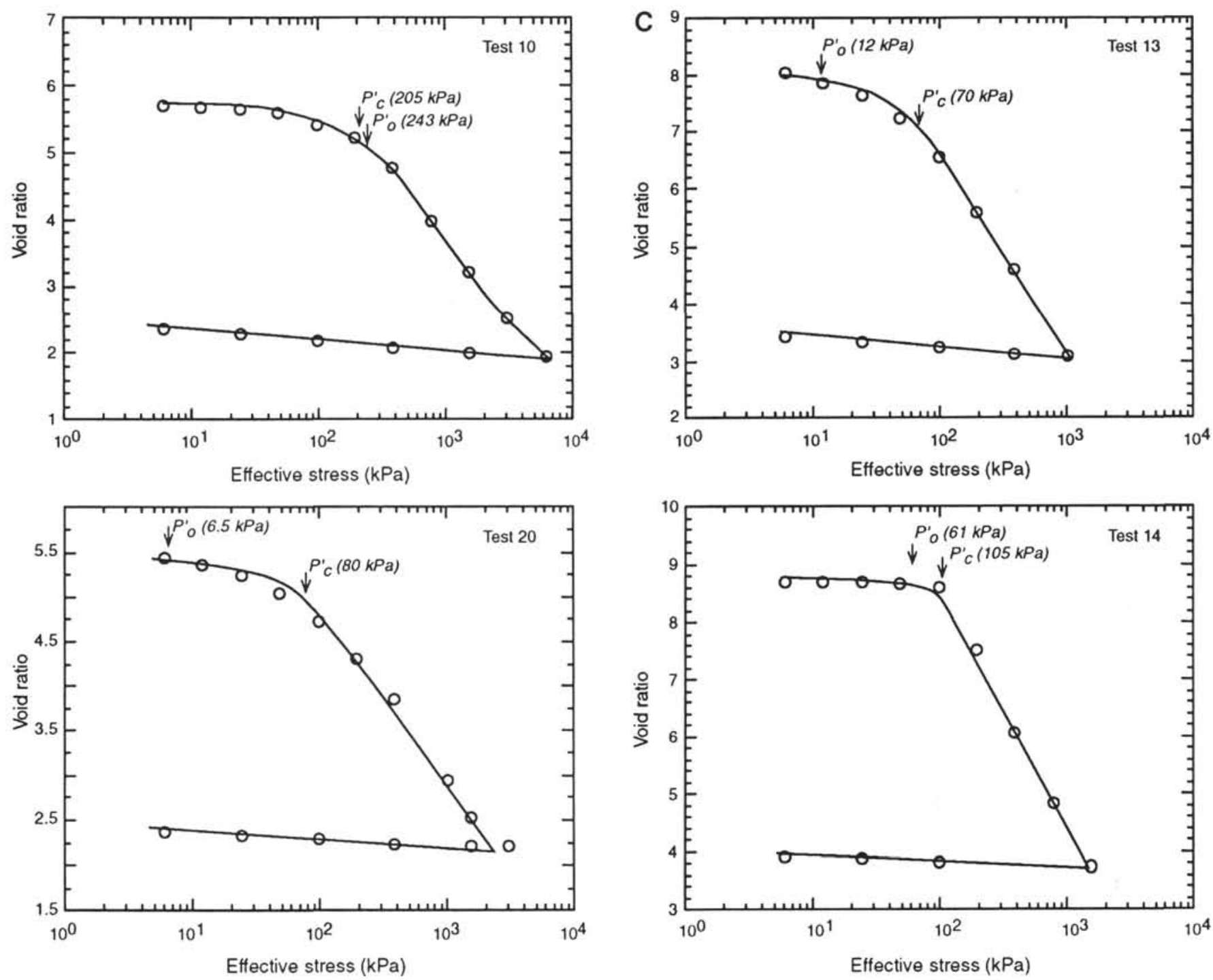

Figure 3 (continued).

847. The siliceous sediments were characterized by high initial void ratios (3.83-6.65) and high compression and expansion coefficients. $C_{c}$ values ranged from 1.19 to 2.63 , with an average of 1.64 (Table 2). Pittenger et al. (1989) measured $C_{c}$ values that ranged from 1.38 to 3.20 for six siliceous ( $>35 \%$ silica) sediment samples from the Norwegian Sea. Marsters and Manghnani (1993) obtained a $C_{c}$ value of 1.14 for a radiolarian ooze recovered from the Ontong Java Plateau.

Expansion $\left(C_{r}\right)$ indexes ranged from 0.072 to 0.167 , with a mean of 0.119 . Pittenger et al. (1989) obtained rebound values that ranged from approximately 0.105 to 0.220 . Marsters and Manghnani (1993) measured a $C_{r}$ value of 0.066 .

$P<D_{c}^{\prime}$ values for the siliceous sediment tests ranged from $57 \mathrm{kPa}$ in the shallowest sample to $260 \mathrm{kPa}$ in the deepest of the siliceous ooze samples (Fig. 3B; Table 2). The samples varied from overconsolidated in the shallowest intervals to underconsolidated in the deepest intervals, reflecting the small variation in $P_{c}^{\prime}$ with depth for this lithology.

\section{Siliceous Clay}

The siliceous clay samples consisted of clay with diatoms and radiolarians. Consolidation tests were conducted on five samples from Sites 844 and 845 having clay contents greater then $70 \%$, opal content from $8 \%$ to $23 \%$, and carbonate content of less than $5 \%$ (Table 1). The

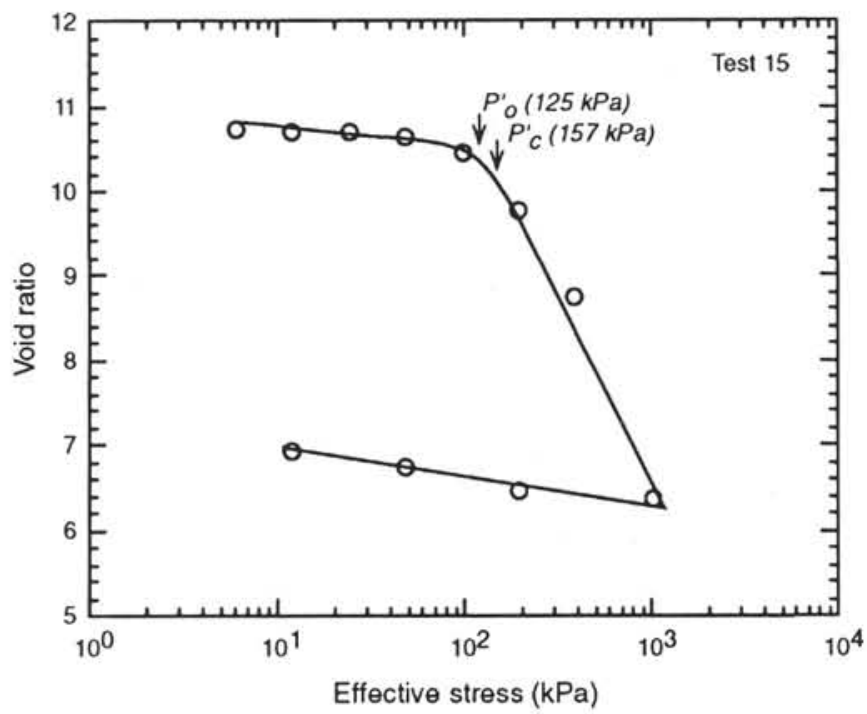

Figure 3 (continued). 

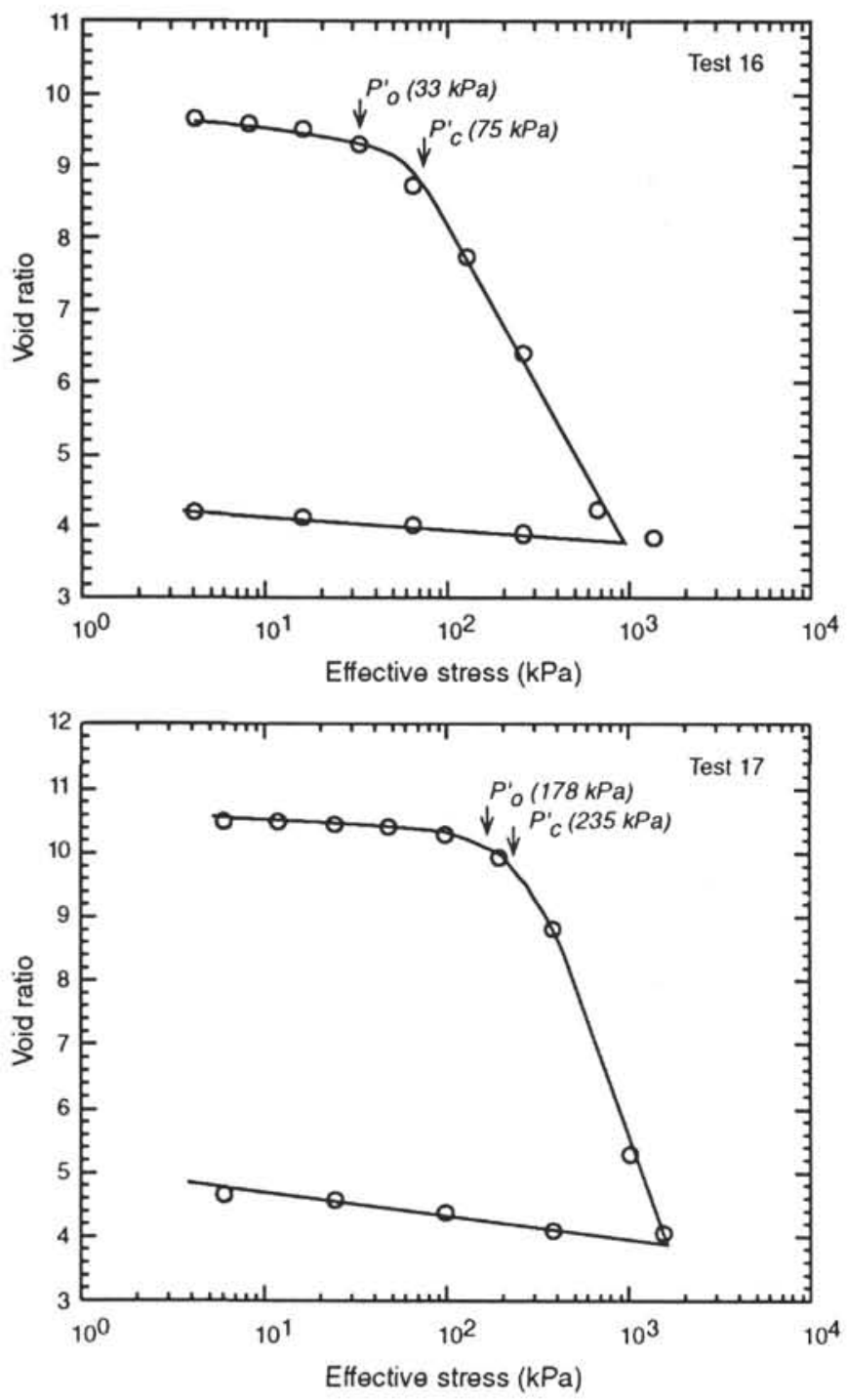

Figure 3 (continued).

predominate clay mineral is smectite (Mayer, Pisias, Janecek, et al., 1992), which strongly influences the deformation behavior of the sediments. These clay-rich sediments were characterized by very high initial void ratios (8.15-10.75) and high compression and expansion indexes. $C_{c}$ values ranged from 3.40 to 7.95 , with an average of 4.96 (Table 2). Silva and Jordan (1984) obtained lower $C_{c}$ values that ranged from 2.46 to 3.10 for smectite-rich clays from the north central Pacific. The initial void ratios reported by Silva and Jordan (1984) for these clays were also lower (4.47-7.12).

Expansion indexes measured on siliceous clay samples ranged from 0.175 to 0.374 , with an average of 0.242 . The $C_{r}$ values estimated from $e-\log P^{\prime}$ curves of Silva and Jordan (1984) were higher than 0.30 , likely the result of the higher smectite content of samples in their study area, the north central Pacific.

Siliceous clay $P_{c}^{\prime}$ values ranged from $70 \mathrm{kPa}$ in the shallowest sample to $235 \mathrm{kPa}$ in the deepest (Fig. 3C; Table 2). The unique aspect of the siliceous clay samples was their very high void ratios. Although these void ratios were high, all samples tested in the overconsolidated range.

\section{Porosity}

One of the primary reasons for determining the elastic rebound of the sediments was to correct the laboratory-determined index proper- ties, including porosity, to in-situ values, particularly in the upper 80 to $100 \mathrm{mbsf}$, where downhole log data were not available. Hamilton (1976) described a procedure for estimating rebound from derived rebound-depth functions using results of consolidation tests. The rebound-depth functions, then, are used to correct laboratory data to in-situ values. Marsters and Manghnani (1993) used Hamilton's procedure to calculate a rebound-depth function for calcareous oozes from the Ontong Java Plateau. Both methods are good approximations for a uniform lithology. In these more variable sedimentary sections (e.g., interbedded siliceous and calcareous ooze), we chose to apply an elastic rebound correction at each index property measurement, based on an excellent correlation between void ratio and elastic rebound (Fig. 4). $C_{r}$ values were selected at each index property depth interval using the relationship of void ratio vs. rebound, which was applied for all of the eastern transect consolidation data. These $C_{r}$ values then were assigned to discrete measurement intervals.

Laboratory index data were corrected by applying the log-linear function of the consolidation curve ( $d$ to $e$; Fig. 2) described by its slope, $C_{r}$. The void ratio for each discrete index measurement was corrected to in-situ void ratio $\left(e_{c}\right)$ as follows:

$$
e_{c}=e_{i}-\left[\left(\log P_{o}^{\prime}\right) C_{r}\right]
$$

where $e_{c}$ is the corrected void ratio, $e_{i}$ is the laboratory-determined void ratio, and $P_{o}^{\prime}$ is the effective overburden pressure calculated for the depth of the index measurement. Porosity, corrected for elastic rebound $\left(n_{c}\right)$ then was calculated using the following phase relationship:

$$
n_{c}=e_{c} \div\left(1+e_{c}\right) \text {. }
$$

In a similar manner, bulk-density $(\rho)$ data were corrected to in-situ values.

Corrected porosities for all sites of the eastern transect show distinct characteristics within each lithology (Fig. 5). In general, porosities are high for all sediment types of the eastern transect. However, porosity and the other index properties vary with lithology to the first order and do not display significant compaction-related changes with depth below seafloor. For example, large offsets in porosity can be seen at lithology breaks at 75 mbsf in Hole 844B and at $136 \mathrm{mbsf}$ in Hole $845 \mathrm{~A}$, where there is a marked increase in carbonate content below the break. However, only small decreases in porosity occur within each lithologic unit with depth. This is clearly seen in the upper $136 \mathrm{~m}$ of Hole $845 \mathrm{~A}$, where porosity shows no reduction with depth (Fig. 5).

Porosity profiles at Sites 846 and 847 vary as a function of lithology as at the other sites, but reflect the more complex stratigraphy that was observed. The porosity for these sites also was high $(>60 \%)$ with no significant decrease with depth.

An estimated normally consolidated compaction function was computed for each site using the slope of the virgin compression curve $\left(C_{c}\right)$. The compaction curves were constructed using average $C_{c}$ values for each lithology. Compaction functions were computed by applying the log-linear function of virgin compression to obtain the normally consolidated void ratio $\left(e_{n c}\right)$ at each depth interval as follows:

$$
e_{n c}=e_{o}-\left[\left(\log P_{\mathrm{o}}^{\prime}\right) C_{c}\right] \text {, }
$$

where $e_{o}$ is the initial sediment void ratio that was estimated by averaging the void ratio values from the first section of the first core at each hole. This void ratio then was converted to the estimated normally consolidated porosity using the standard phase relationship (Eq. 2).

The predicted normally consolidated porosity-depth functions were compared to the actual porosity measurements (Fig. 5). In Hole 844B, the measured porosities were predominantly lower than the predicted porosity-depth function, suggesting that although the sediment retains high void ratios, it may still be overconsolidated. Data from Hole 845A 


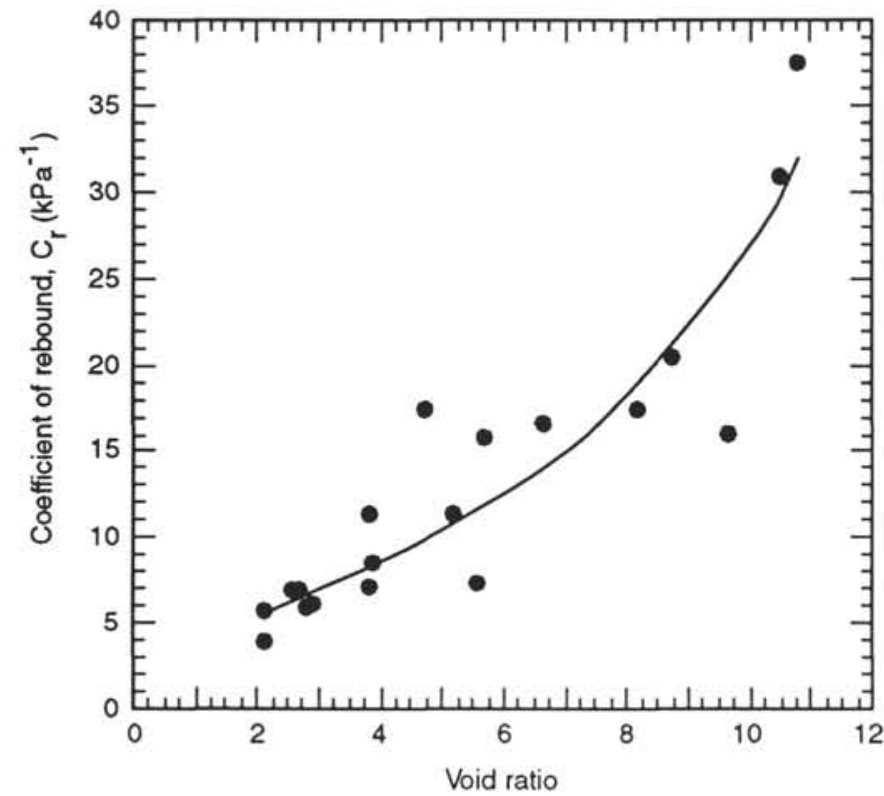

Figure 4. Coefficient of rebound, determined from the slope of the unloaded portion of consolidation tests plotted as a function of initial sample void ratio. Dashed line $=$ a least-squares exponential regression used to assign $C_{r}$ values to each index property depth interval. The exponential function is $C_{r}=$ $4.0 e^{(0.19 e)}$. The curve fit using this equation results in $R=0.91$.

suggest a different trend. The upper $20 \mathrm{~m}$ of Hole $845 \mathrm{~A}$ appeared to be normally consolidated, where the predicted and measured porosity values were closely matched. Between 20 and 136 mbsf in Hole 845A, the measured porosity data were higher than those predicted, suggesting that the normal consolidation process of porosity decrease with depth had been suppressed. Below 136 mbsf in Hole 845A, measured porosity did not vary significantly from the predicted curve. Predicted normally consolidated porosity-depth functions for Holes $846 \mathrm{~B}$ and $847 \mathrm{~B}$, when compared with measured data, showed predominantly normal to slightly overconsolidated behavior, with a few excursions toward underconsolidation that occurred over the intervals of 50 to 150 mbsf and 250 to $340 \mathrm{mbsf}$ in Hole $846 \mathrm{~B}$ and over the interval of 40 to $65 \mathrm{mbsf}$ in Hole $847 \mathrm{~B}$.

\section{Stress History}

The consolidation state of each sample was determined directly from the consolidation tests by comparing the measured $P_{c}^{\prime}$ with the calculated overburden stress $P_{o}^{\prime}$ (Fig. 6, Table 2). Overconsolidation $(\mathrm{OCR}>1)$ was the dominant stress history, with only two exceptions that occurred in Hole 847B. These two tests showed underconsolidation, suggesting high sedimentation rates within the lithologies associated with these sample intervals: 91 to 92 and 133 to 135 mbsf. With the exception of Hole $845 \mathrm{~A}$, OCR values from consolidation tests were consistent with the stress history interpretation from the porosity data comparison to the predicted normally consolidated compaction curve (Fig. 5). This consistency adds confidence to the interpreted stress history for these sites, suggesting that the sediment from Sites 844,846 , and 847 may truly be overconsolidated (i.e., the increased $P_{\text {c }}^{\prime}$ was caused by a reduction in porosity from erosional removal of sediment, dissolution, or diagenesis). Diagenetic processes, in the form of cementation, have been suggested as the mechanism for overconsolidation in similar deep-sea sediments (Marine Geotechnical Consortium, 1985).

Within the clay-rich interval of Hole $845 \mathrm{~A}(0-136 \mathrm{mbsf})$, all four consolidation test $\mathrm{OCR}$ values were greater than one. A comparison of corrected porosity (Fig. 5) with predicted porosity-depth function, however, suggests the opposite stress history, underconsolidation.
This "apparent overconsolidation," interpreted from the consolidation tests, may be attributed to the intrinsic strength of the sediment created by radiolarian or diatom skeletal spines that formed an interlocking structure. This microfabric enhanced the strength of the sediment, thus increasing $P_{c}^{\prime}$ values without reducing porosity. Shipboard undrained shear strength measurements were consistent with these high $P_{c}^{\prime}$ values. The shear strength of siliceous clay intervals increased with depth as a function of $0.5 \mathrm{kPa} / \mathrm{m}$, as compared to intervals of carbonate ooze, which increased at $0.2 \mathrm{kPa} / \mathrm{m}$ (Mayer, Pisias, Janecek, et al., 1992).

\section{Depth Offsets}

The removal of overburden pressure during the sampling process is directly analogous to the unloading part of the consolidation test ( $d$ to $e$, Fig. 2), where void ratio increases as a result of rebound of the elastic component of sediment deformation behavior. When core is recovered on deck, it has undergone elastic rebound as it travels up the drill string, which results in expansion of the core and, in many cases, greater than $100 \%$ core recovery. The core tube maintains the sample confined in the horizontal plane; thus, we can assume that the core sample rebounds elastically in one dimension. Therefore, all of the elastic rebound corresponds directly to a lengthening of the core sample. Using Equation 1, the void ratio change resulting from elastic rebound can be calculated. This change in void ratio over one core length is geometrically related to the increase in core length or core length expansion $(\Delta L)$. The predicted $\Delta L$ over discrete measurement intervals was calculated from the elastic response change in void ratio as follows:

$$
\Delta L=\Delta e\left(L_{o}-n L_{o}\right)
$$

where $L_{o}$ is the length of unrebounded core $(9.5 \mathrm{~m})$ and $n$ is the porosity measured at each sample interval. Because $\Delta e$ is directly related to the log-linear elastic sediment response, which varies with pressure, it increases with increasing effective overburden stress (depth below seafloor) and, thus, $\Delta L$ also increases with depth.

This core length expansion results in recovery of greater than the cored length, $9.5 \mathrm{~m}$. Therefore, if upon core pull out, $100 \%$ recovery is achieved, the difference between the actual recovered core length and the cored length $(9.5 \mathrm{~m})$ should be a good approximation of the elastic expansion of the sediments. The estimate of $\Delta L$ using consolidation results was compared with the length of recovered core greater than $9.5 \mathrm{~m}\left(\Delta L_{r e c} ;\right.$ Fig. 7). Core elastic expansion predicted from the consolidation results (rebounded APC core; Fig. 7) matches the physically measured expansion of each core (recovered APC core; Fig. 7) well. This correspondence is a check on our application of the elastic expansion coefficient $\left(C_{r}\right)$ to the prediction of core rebound.

The ODP core depth is determined directly from the length of the core pipe and is recorded as meters below seafloor (mbsf), with the mud line assigned a depth of zero. The tops of successive cores are assigned depths, based on the core technician's recorded depth of the drill string. These depths are usually assigned in $9.5-\mathrm{m}$ increments when the APC has had a full stroke (i.e., complete penetration into the formation). Once the top of the core is assigned a depth in meters below seafloor, each interval in that core is incrementally added to the top depth to obtain interval depth. After an APC core is recovered, the drill string is nominally advanced $9.5 \mathrm{~m}$, the length of the unrebounded core, in preparation for advancing the next APC core. Thus, the depth (in mbsf) calculation does not incrementally add elastically expanded core length.

The paleoceanographic objectives of Leg 138 required the recovery of a complete stratigraphic section. Hagelberg et al. (1992) described the Leg 138 shipboard procedure for constructing a composite depth section from two to four holes drilled at each site. The process described by Hagelberg et al. (1992) positions one core from one hole at a fixed depth and then using wave-form matching of MST and color- 

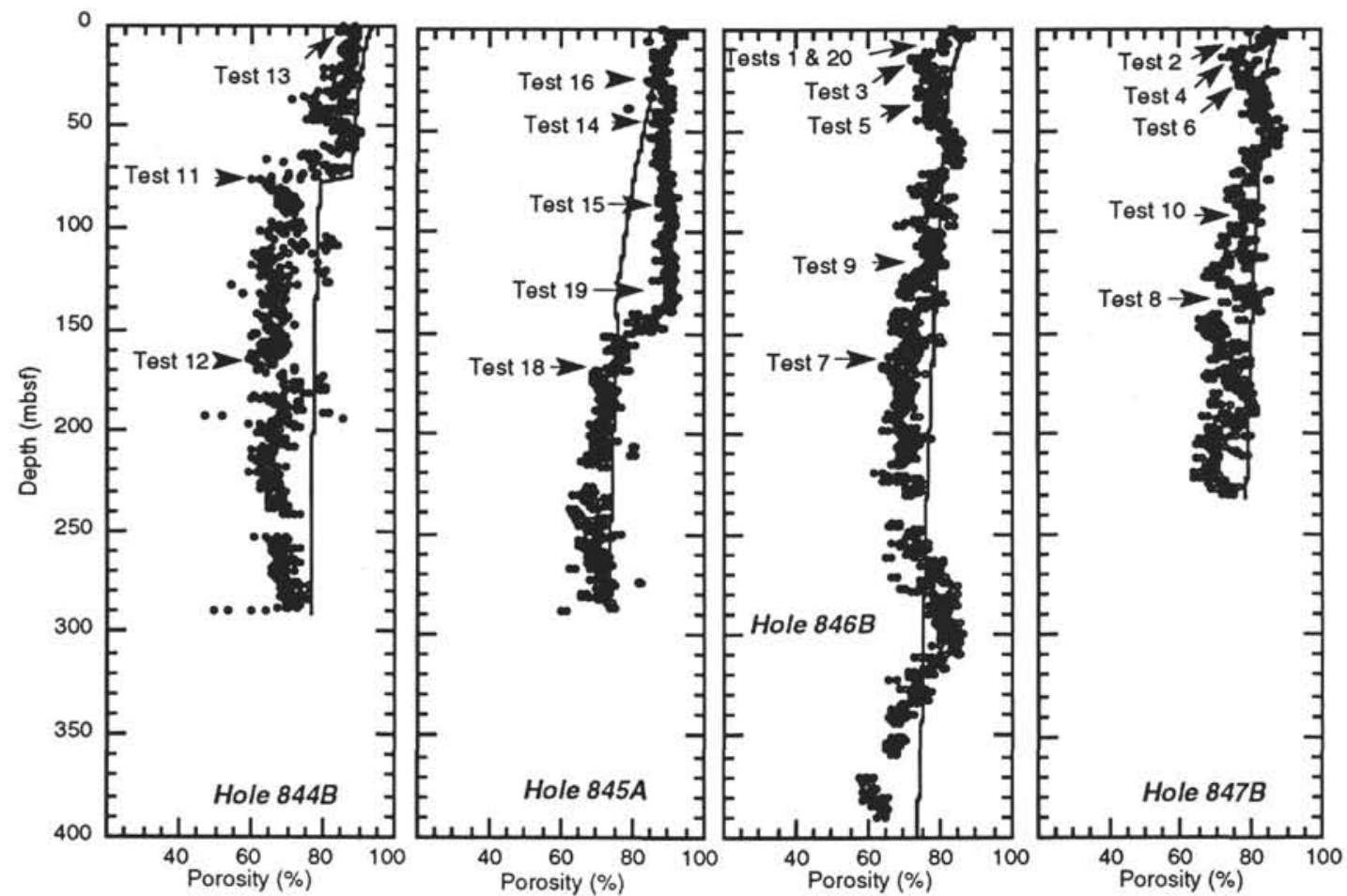

Figure 5. Porosity plotted as a function of depth below seafloor for the four holes included in this study. Open circles represent uncorrected porosity data; solid circles have been rebound-corrected; and the solid line is the predicted normally consolidated porosity-depth function for the lithologies in each hole.
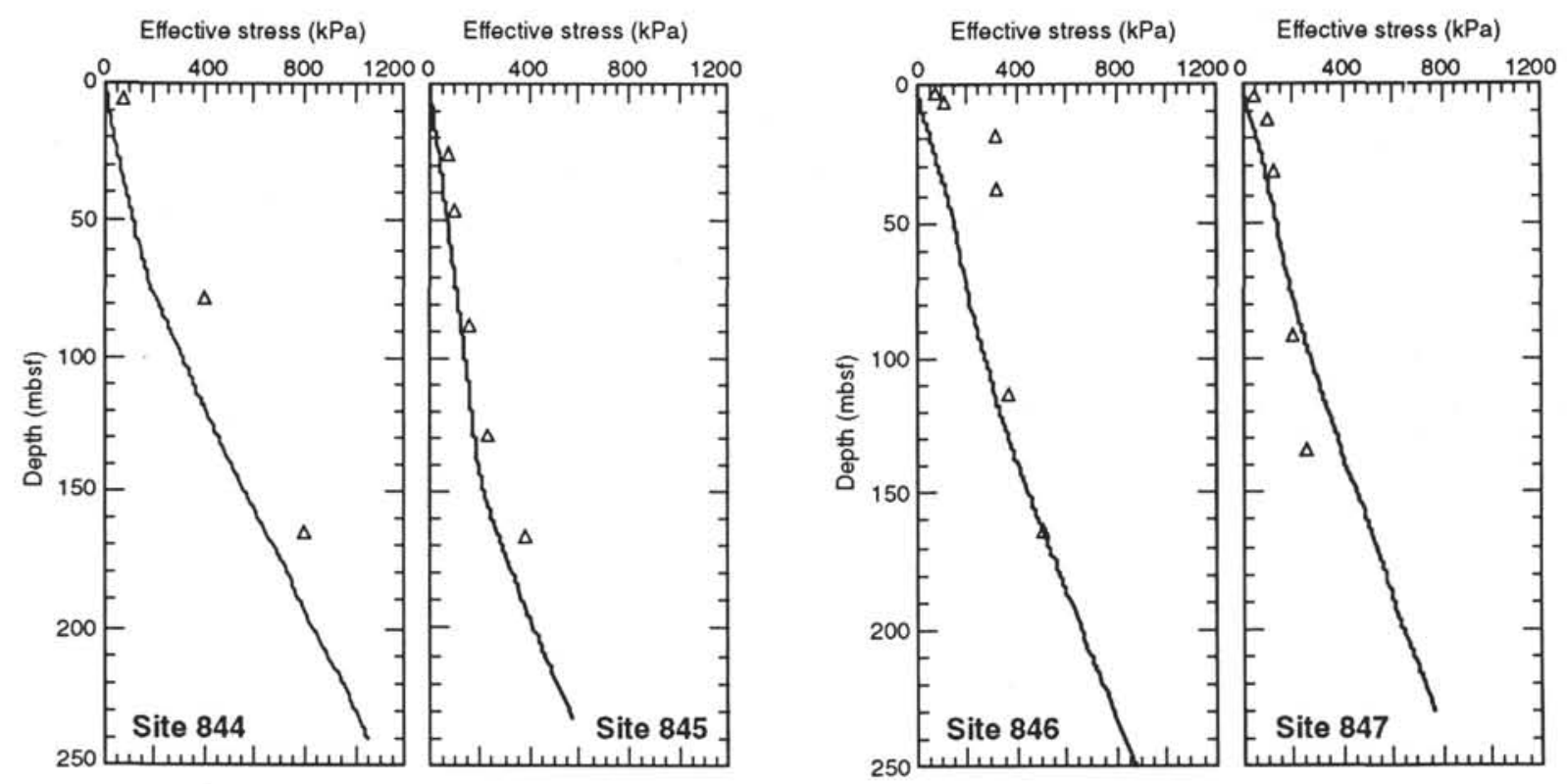

Figure 6. Overburden (solid line) and preconsolidation stress (triangles) plotted with depth for the four holes included in this study. Effective overburden stress was calculated from sediment buoyant unit weight, which was derived from bulk-density measurements; preconsolidation stress was determined from consolidation tests.

reflectance data, all of the other cores from the site are positioned in depth. The rules that were applied in their composite construction are (1) core data are not allowed to be stretched or compressed in relative depth, (2) cores in any one hole must remain in consecutive depth order; and (3) individual cores are allowed to slide up and down in depth, thus either "creating" core overlaps or gaps in any one hole. Hagelberg et al. (1992) presented composite depth scales for all of the sites drilled during Leg 138. All of these modified core depths (mod) result in individual core shifts that are biased toward core gaps as opposed to a combination of core gaps and core overlaps. Consequently, when a comparison is made between the mbsf depth scale and the mod depth scale in any one hole, the mcd scale is a maximum of $35 \mathrm{~m}$ longer than the deepest hole drilled at a specific site. For example, at Site 847 , the amount of offset at the ODP depth interval 


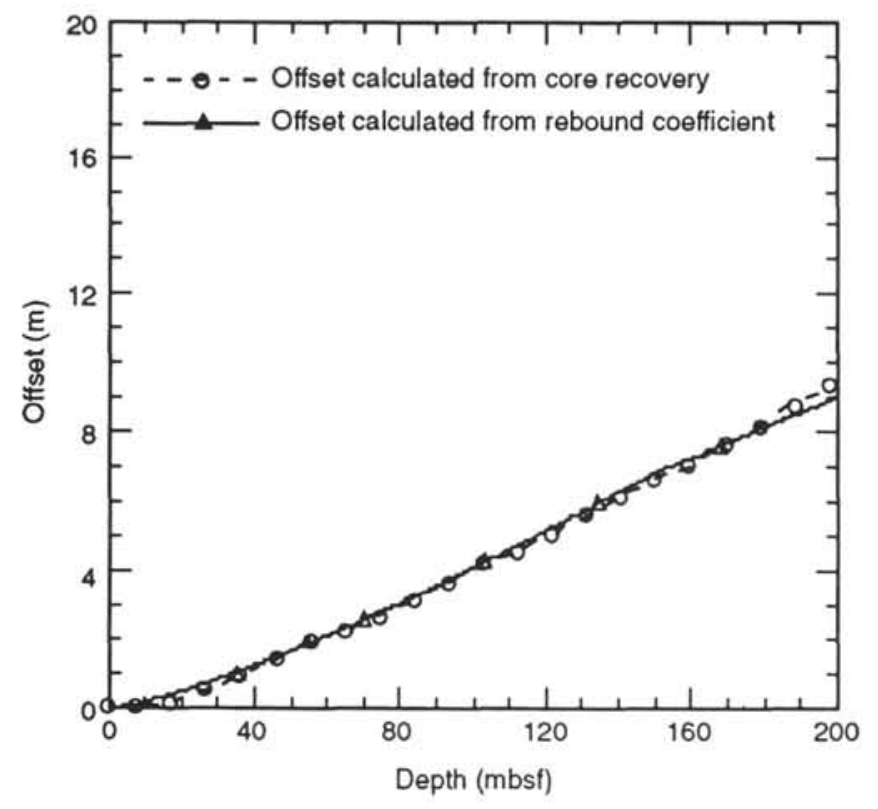

Figure 7. Offsets plotted as a function of depth below seafloor for Hole $845 \mathrm{~A}$. Offset is defined here as the difference between core length that has elastically expanded due to stress relief. Two offsets have been plotted here. One offset (circles) was calculated from the actual difference between the recovered core length and the length that the core is advanced into the formation $(9.5 \mathrm{~m})$. The other offset (triangles) was calculated from the rebound coefficient measured in the consolidation test. The close match between the two independent offset calculations provides confidence in the prediction of elastic core expansion.

of $140 \mathrm{mbsf}$ in Hole $847 \mathrm{~B}$ is $16.2 \mathrm{~m}$. This offset means that the compiled data sets (composite) from all three holes at Site 847 to this depth interval are $16.2 \mathrm{~m}$ longer than any individual hole's measured depth. This lengthening can only be attributed to two types of physical phenomena: (1) core stretch (i.e., elastic expansion) and/or (2) core gaps where sections are not recovered and thus the core is shifted deeper (i.e., longer) to accommodate the gap. The amount of lengthening which can be attributed to the physical elastic core expansion at this depth $(1.4 \mathrm{~m})$ is $5.2 \mathrm{~m}$ (Fig. 8). The remaining offset (11 m), therefore, must be attributed to either actual gaps between successive cores or to errors in the construction of the composite depth section.

To check for actual gaps that would cause the composite depth to extend deeper than the drill string-measured depth, density measurements from core samples referenced to mbsf depth were compared with the density downhole log at each of the four sites. Downhole logs are referenced to a wireline depth reference. Any actual physical gaps that occur between consecutive cores in any one hole will be seen as offsets between the downhole log and core data, because the downhole $\log$ measures in-situ density of the borehole wall with no record gaps. Overall, the comparison of the GRAPE-measured bulk-density to discrete laboratory bulk-density data is good. GRAPE data were sampled at the same depth interval as discrete measurements for Hole $847 \mathrm{~B}$ (Fig. 9A). The mean of the difference between GRAPE-measured bulk-density and discrete laboratory-measured bulk-density is 0.01 $\mathrm{Mg} / \mathrm{m}^{3}$, which is less than the error of the discrete measurements $\left( \pm 0.02 \mathrm{Mg} / \mathrm{m}^{3}\right)$. The variance of the difference between the two data sets is also small, 0.002 . Similarly, the downhole log-measured bulkdensity visually correlates with the discrete laboratory-measured bulkdensity (Fig. 9B). A statistical evaluation of how well the log data compares with the discrete laboratory bulk-density data is dependent upon the type of filters applied to each data set, which is outside the scope of this study. The most striking observation from the comparison of $\log$ to laboratory bulk-density is that the data sets compare very well

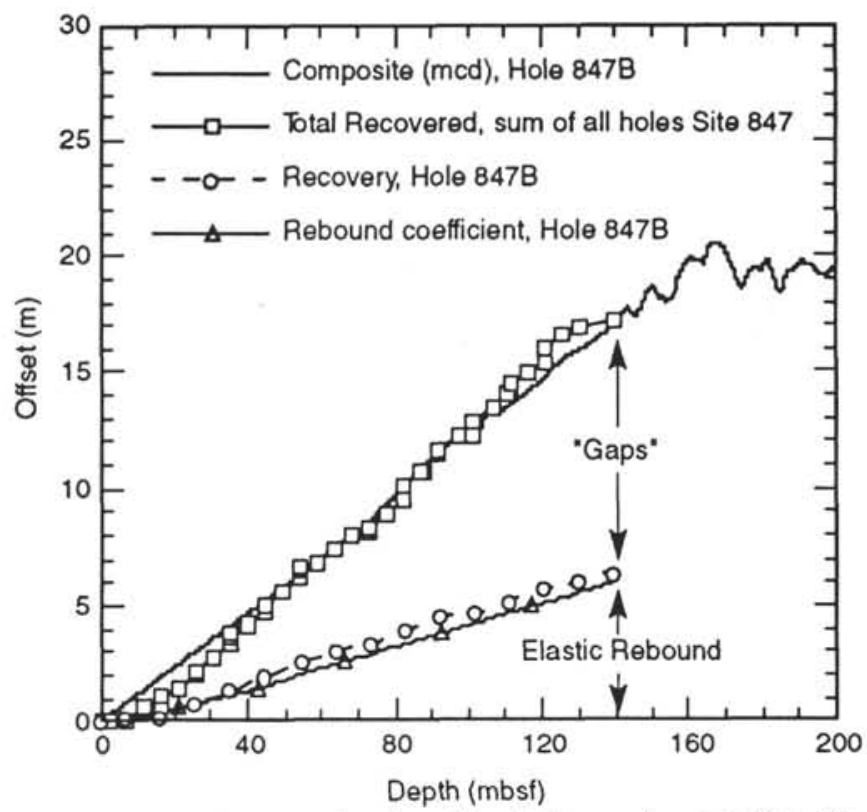

Figure 8. Offsets plotted as a function of depth below seafloor (mbsf) for Site 847. Offsets plotted for recovered core (circles) and the rebound coefficient (triangles) were determined the same way as at Hole 845A (Fig. 7). The offset between the mbsf depth from Hole $847 \mathrm{~B}$ and the length of the composite depth (mcd) has been plotted as the solid line and shown here compared with the recovered core offset, summed for all of the holes at Site 847 (solid squares). This good comparison strongly suggests that duplicated intervals have been inserted into the composite section. The difference between the composite depth offset and the rebound offset has been physically attributed to "gaps" between successive cores, which may cause an accumulation in the offset with depth below seafloor.

in depth (Mayer, Pisias, Janecek, et al., 1992) which shows that gaps do not accumulate downhole, as is suggested by the increasing offset of mcd with depth. Rather, as would be expected for a heaving drill string, some cores are shifted up with reference to the log data and some are shifted down (Fig. 9B). For example, looking again at 140 mbsf for Hole $847 \mathrm{~B}$, the remaining mod offset $(11 \mathrm{~m})$ cannot be attributed to actual core gaps because the maximum difference in offset between core and log data is $1.4 \mathrm{~m}$ (Fig. 9B).

The remaining explanation for the lengthening of the composite section is that there is an error. In an effort to resolve potential systematic errors, we compared a number of different coring parameters with the composite depth offset. At Site 847, we compared the total rebound length of recovered APC cores summed for all three holes drilled at the site against the composite offset of Hole 847B. The rebound length is the total length recovered minus the cored interval $(9.5 \mathrm{~m})$. We summed this length from all APC cores in all three holes. This length represents all of the additional core recovered for the entire site (Fig. 8 ). This summed length from all three holes matches the composite offset for only one hole, $847 \mathrm{~B}$. This suggests that the composite stratigraphic section has been constructed with duplicate sections. If no duplicate sections were incorporated into the composite, then given the lack of accumulated gaps between cores, the length of the rebounded core would match the composite offset for any given hole.

The difference between the composite offset and elastic rebound offset in any one hole has been suggested by Hagelberg et al. (1992) to be gaps, as described above. We have analyzed this "gaps" difference for one hole per site. This analysis is most revealing in terms of delineating systematic errors. At Site 847 , for example, the "gaps" difference for only one hole at that site, Hole $847 \mathrm{~B}$, is equal to an added $25 \mathrm{~cm}$ for all of the cores in all of the holes at the site (Fig. 10). Again this suggests that the composite offset incorporates duplicate section 

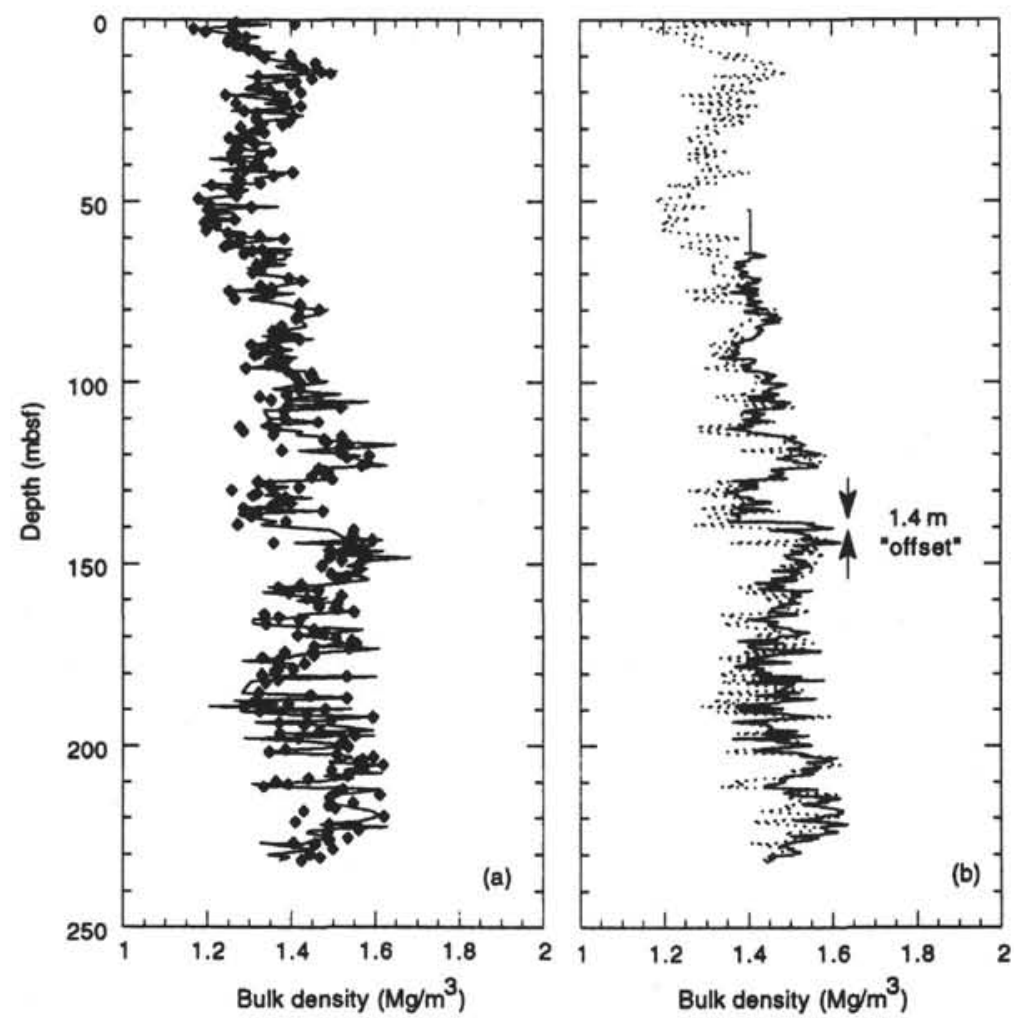

Figure 9. A. Bulk-density measured on discrete samples (diamonds) plotted with GRAPE bulk-density sampled at discrete interval depths (line) for Hole 847B. Excellent correlation exists between the two independent measurements of bulk density. B. Discrete laboratory bulk-density measurements corrected for elastic rebound are plotted with bulk-density measured from downhole logging for Hole 847B as a function of mbsf. The absolute values show good correlation. In some intervals, the core data plot slightly deeper than the equivalent log data; in others, the core data plot slightly shallower; and over many intervals. the core data and log data match (Mayer, Pisias, Janecek, et al., 1992). For example, if the accumulated "gaps" $(11 \mathrm{~m})$ based on the mcd offset at $140 \mathrm{mbsf}$ occur, then one would expect an $11-\mathrm{m}$ shift in core data deeper than the log data. As indicated by the arrow at $140 \mathrm{mbsf}$, the core data have shifted only $1.4 \mathrm{~m}$ deeper than the $\log$ data. These data show that there are no accumulated gaps in the core record as suggested by the composite depth section.

lengths that systematically have been included in approximately 25 $\mathrm{cm}$ to $30 \mathrm{~cm}$ length increments. The most serious implication of this error is the likelihood that the composite stratigraphic section includes duplicated stratigraphy, which in a paleoceanographic sense, is duplicated signal in the time series record.

On Leg 138, coring operation procedures consistently provided core overlap in successive APC's. The APC design incorporates a 9.8 $\mathrm{m}$ long core sample chamber which is confined by the core-catcher at the bottom of the sampler and by the piston at the top of the sampler. Each APC extends into the formation $9.8 \mathrm{~m}$ and is then recovered. After recovery, the drill string is advanced $9.5 \mathrm{~m}$, in preparation for advancing the next APC. Approximately $0.3 \mathrm{~m}$ of sediment, therefore, can potentially be recovered as overlap in stratigraphy in each core sample. If hole conditions were perfect and if the drill string did not move laterally, then the overlap would recover a void. Hole conditions are never perfect, however, and the drill string does move laterally in the hole. Several scenarios can occur. If the drill string remains vertical and sloughing of sediment occurs in the hole, then disturbed drilling slough will be recovered as the overlap. If the hole remains relatively stable and the drill string moves laterally relative to the previous core, then undisturbed sediment that were recovered at the bottom of the previous core would comprise the overlap. These scenarios are also affected by the vertical heave of the drill string. In the construction of the composite section, if a gap is assumed to occur between successive cores in one hole which should have been an overlap, additional gaps must be inserted between successive cores in all other holes at the site. The deliberate Leg 138 core overlap drilling operations and the rules for composite construction enhance the erroneous growth of the composite depth section.

\section{CONCLUSIONS}

Sediment recovered from the eastern transect of Leg 138 is predominantly overconsolidated, based on the overconsolidation ratio values. This overconsolidation is reflected in two ways in the porosity-depth profiles of the sites. At Sites 844,846 , and 847 , sediment porosity is predominantly lower than the predicted normally consolidated compaction curve. Consequently, overconsolidation at these sites is caused by porosity loss, either through erosion of overburden, dissolution, or through porosity-reducing diagenetic processes (e.g., cementation; Lee, 1982). At Site 845 in the upper 136 mbsf, overconsolidation has a different characteristic. Although sediment from this interval is overconsolidated, porosity is higher than the predicted normally consolidated compaction curve. Consequently, Site 845 overconsolidation must be a function of the radiolarian and diatom microfossils that strengthen the sediment microfabric. This strength is developed early during initial deposition of the sediment as can be seen by the almost constant porosity profile in this interval. As the 


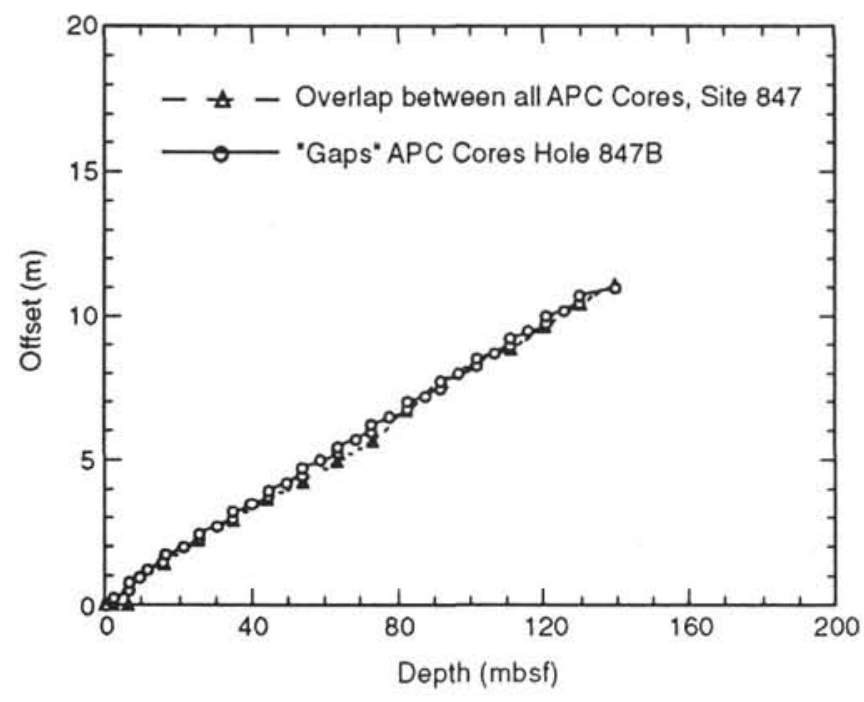

Figure 10. The ODP APC-coring method results in an overlap of 25 to $30 \mathrm{~cm}$ between successive cores. The difference between the mcd offset and rebound offset has been identified as "gaps." At Site 847 , excellent correlation can be seen between the gap offset (triangles) and an overlap of $25 \mathrm{~cm}$ (circles) among all the cores recovered at Site 847 .

sediment is subjected to increased overburden stress with time, this stress is taken up by the relatively high brittle strength of the interlocking fossils, rather than by the pore fluid, which then would induce consolidation and porosity loss.

The discrete index and GRAPE density measurements have been corrected to in-situ values using the consolidation-measured elastic rebound. These corrected data correlate well with the downhole log measurement of density. In addition to correlating in absolute density value, the comparison of core to log density showed that there are only small shifts in core mbsf depth relative to the log wireline depth. Thus, gaps between successive cores cannot account for the cumulative lengthening of the composite depth reference (mcd). Only elastic rebound can account for some portion of the lengthening or offset in mcd. Consequently, we suggest that the difference between the total mcd offset and the elastic rebound offset reflects an error in the construction of a composite section. This error is most likely associated with the standard drilling operations which recover an average of $0.3 \mathrm{~m}$ of overlap sediment with each core.

The mcd scale lengthens the total stratigraphic section by as much as $35 \mathrm{~m}$. Hagelberg, et al. (1992) associated this offset in length with drilling errors, specifically gaps. The fact that drilling errors should be biased toward gaps does not make physical sense. Drill-string heave occurs in both directions and, thus, at times cores will show a repeated sampling interval (overlap) when the core is advanced during a high drill-string heave and will miss a sampling interval (gap) when the core is advanced during a low drill-string heave. The comparison of any individual mbsf density profile with log data confirms this where, in some intervals, the core data are shifted higher than the equivalent log interval; in other intervals, the core data are shifted lower; and over many intervals, the core and log data exhibit no offset. This phenomenon of both gaps and overlaps has also been documented by others (Ruddiman et al., 1987).

Because of the risk of errors in the Leg 138 composite construction method, we suggest an alternative approach be used for the construction of composite sections. The method used for Leg 138 data is analogous to the processes of levelling a table with four legs. If one leg is not anchored and used as the reference level, the process will cause the table to become higher and higher as more match books are put under each leg. However, if one leg is fixed as an anchor and not allowed to move, then all of the others can be adjusted to that level, either up or down. One core in one hole is not a sufficient anchor for the construction of composite sections.

An alternative approach utilizes logging data to develop a suitable anchor for constructing the composite section for paleoceanographic legs. This approach comprises the following five steps:

1. Select two consistent data sets, one from the core data and one from the wireline log data and apply a running average to the core data to approximate the vertical resolution of the log data. Apply this average to the core data from the hole where the log was run.

2. Apply a compression function to the core data, based on the percentage of core recovery to remove the effects of elastic core rebound.

3. Using a crosscorrelation technique, correlate the compressed core data with the log data. The outcome of this will be a depth transform function of core data to wireline log depth for the entire depth range of the wireline log. The core data, in terms of wireline depth now will serve as the anchor for composite construction.

4. Again, using crosscorrelation, correlate all cores (unaveraged) from the other holes to the "anchored" hole data. This step will provide a transform function for all of the other core data to the wireline depth.

5. The upper 5 or 6 cores of each hole cannot be used in the above correlation process because they do not overlap with the downhole logs. These remaining cores should be correlated using two anchors: the shallowest core in the anchor hole that has been correlated with the wireline log and the mud-line core. A crosscorrelation technique can be used in an iterative mode until all cores fit within these two anchor positions with depth.

This proposed technique would restrict the "growth" of the composite section and provide confidence in the construction of a complete stratigraphic section.

\section{ACKNOWLEDGMENTS}

We thank Frank Rack and an anonymous reviewer for comments and suggestions that improved the manuscript. Thanks also to Nick Shackleton for providing additional comments that improved the clarity of the text. This is Geological Survey of Canada Contribution No. 16394.

\section{REFERENCES*}

Athy, L.F., 1930. Density, porosity and compaction of sedimentary rocks. AAPG Bull., 14:1-24.

Brückmann, W., 1989. Typische Kompakationsmuster mariner Sedimente und ihre Modifikation in einem rezenten Akkretionskeil (Barbados Ridge). Beitr. Geol. Inst. Univ. Tübingen, Rh. A, 5:1-135.

Casagrande, A., 1936. Determination of preconsolidation load and its practical significance. Proc. 1st Conf. Soil Mech. and Found. Eng. (Vol. 3). Am. Soc. Civ. Eng., 60-64.

Demars, K.R., 1982. Unique engineering properties and compression behavior of deep-sea calcareous sediments. In Demars, K.R., and Chaney, R.C. (Eds.), Geotechnical Properties, Behavior, and Performance of Calcareous Soils. ASTM Spec. Tech. Publ., 777:97-112.

Hagelberg, T., Shackleton, N., Pisias, N., and Shipboard Scientific Party, 1992. Development of composite depth sections for Sites 844 through 854 . In Mayer, L., Pisias, N., Janecek, T., et al., Proc. ODP, Init. Repts., 138 (Pt. 1): College Station, TX (Ocean Drilling Program), 79-85.

Hamilton, E.L., 1976. Variations of density and porosity with depth in deep-sea sediments. J. Sediment. Petrol., 46:280-300.

Lee, H.J., 1982. Bulk density and shear strength of several deep-sea calcareous sediments. In Demars, K.R., and Chaney, R.C. (Eds.), Geotechnical Properties, Behavior, and Performance of Calcareous Soils. ASTM Spec. Tech. Publ., 777:54-78.

\footnotetext{
- Abbreviations for names of organizations and publication titles in ODP reference lists follow the style given in Chemical Abstracts Service Source Index (published by American Chemical Society).
} 
Lowe, J., Zaccheo, P.F., and Feldman, H.S., 1964. Consolidation testing with back pressure. J. Geotech. Eng. Div., Am. Soc. Civ. Eng., 90:69-86.

Marine Geotechnical Consortium, 1985. Geotechnical properties of northwest Pacific pelagic clays: Deep Sea Drilling Project Leg 86, Hole 576 A. In Heath, G.R., Burckle, L.H., et al., Init. Repts. DSDP, 86: Washington (U.S. Govt. Printing Office), 723-758.

Marsters, J.C., and Manghnani, M.H., 1993. Consolidation test results and porosity rebound of Ontong Java Plateau sediments. In Berger, W.H., Kroenke, L.W., Mayer, L.A., et al., Proc. ODP, Sci. Results, 130: College Station, TX (Ocean Drilling Program), 687-694.

Mayer, L., Pisias, N., Janecek, T., et al., 1992. Proc. ODP, Init. Repts., 138 (Pts. 1 and 2): College Station, TX (Ocean Drilling Program).

Pittenger, A., Taylor, E., and Bryant, W.R., 1989. The influence of biogenic silica on the geotechnical stratigraphy of the Vøring Plateau, Norwegian Sea. In Eldholm, O., Thiede, J., Taylor, E., et al., Proc. ODP, Sci. Results, 104: College Station, TX (Ocean Drilling Program), 923-940.

Ruddiman, W.F., Cameron, D., and Clement, B.M., 1987. Sediment disturbance and correlation of offset holes drilled with the hydraulic piston corer: Leg 94. In Ruddiman, W.F., Kidd, R.B., Thomas, E., et al., Init. Repts. DSDP, 94 (Pt. 2): Washington (U.S. Govt. Printing Office), 615-634.
Silva, A.J., and Jordan, S.A., 1984. Consolidation properties and stress history of some deep sea sediments. In Denness, B. (Ed.), Seabed Mechanics. London (Graham and Trotham), 25-40.

Silvestri, V., Yong, R.N., Soulie, M., and Gabrel, F., 1986. Controlled strain, controlled gradient, and standard consolidation testing of sensitive clays. In Yong, R.N., and Townsend, F.N. (Eds.), Consolidation of Soils: Testing and Evaluation, ASTM STP 892: Philadelphia (ASTM), 433-450.

Taylor, D.W., 1948. One-Dimensional Consolidation: Fundamentals of Soil Mechanics: New York (Wiley).

Terzaghi, K., 1943. Theoretical Soil Mechanics: New York (Wiley).

Valent, P.J., Altschaeffl, A.G., and Lee, H.J., 1982. Geotechnical properties of two calcareous oozes. In Demars, K.R., and Chaney, R.C. (Eds.), Geotechnical Properties, Behavior, and Performance of Calcareous Soils. Philadelphia (Am. Soc. Testing and Materials), 79-96.

Date of initial receipt: 31 March 1993

Date of acceptance: 3 January 1994

Ms 138SR-118 